\title{
MIXTURE OF FORMIC AND PROPIONIC ACID AS ADDITIVES IN BROILER FEEDS
}

\author{
Marcos Martinez do Vale; José Fernando Machado Menten²*; Sônia Cristina Daróz de Morais³; \\ Mônica Maria de Almeida Brainer ${ }^{4}$ \\ ${ }^{1}$ Faculdade de Jaguariúna - Curso de Medicina Veterinária,Rod. Ademar de Barros SP 340, km 127 - $13820-000$ - \\ Jaguariúna, SP - Brasil. \\ ${ }^{2}$ USP/ESALQ - Depto. de Zootecnia, C.P. 9 - 13418-900 - Piracicaba, SP - Brasil. \\ ${ }^{3}$ Nutron Alimentos Ltda., R. Ricardo Bassolli Cesare, 3880 - 13050-080 - Campinas, SP - Brasil. \\ ${ }^{4}$ Escola Agrotécnica Federal de Ceres, Rod. GO 154, km 2 - 76300-000 - Ceres, GO - Brasil. \\ *Corresponding author <jfmmente@esalq.usp.br>
}

\begin{abstract}
The presence of Salmonella species in feeds and ingredients is an important source of salmonella contamination for animals. Organic acid mixtures have shown to be an effective alternative to eliminate salmonellas in feeds and chickens. In the present study, the performance of male broiler chickens receiving levels $(0,0.25,0.50,1.0$ and $2.0 \%$ ) of a mixture of organic acids (OAs) (70\% formic acid and 30\% propionic acid) in the diet was evaluated from the age one to 42 days, in a completely randomized experimental design with five treatments and five replications of 40 birds each. Diets were based on corn, soybean meal and soybean oil. Body weight, weight gain and feed intake from the age one to 21 days were affected by the treatments; $\%$ OAs in the diet reduced body weight and weight gain. Feed intake increased with concentrations of 0.25 and $0.5 \%$ and was reduced with $2 \%$ of OAs. From the age one to 42 days, only feed intake was affected, showing a quadratic effect, increasing at the levels of 0.25 and $0.5 \%$ and decreasing at $2 \%$ of OAs. The mixture of OAs at doses which are effective for the control of salmonella did not affect chicken performance, and the inclusion of $1 \%$ OAs in the diet resulted in a performance similar to that of untreated birds.

Key words: Salmonella, chicken, organic acids, food safety
\end{abstract}

\section{MISTURA DOS ÁCIDOS ORGÂNICOS FÓRMICO E PROPIÔNICO EM RAÇÕES PARA FRANGOS DE CORTE}

\begin{abstract}
RESUMO: A presença de espécies de Salmonella em ingredientes e rações é importante fonte de contaminação dos animais. Entre as medidas visando a eliminação das salmonelas das rações e de frangos, misturas de ácidos orgânicos mostraram-se eficientes. Neste estudo, foi avaliado o desempenho de frangos de corte machos de um a 42 dias de idade recebendo níveis (0, 0,25, 0,50, 1,0 e 2,0\%) da mistura dos ácidos orgânicos (AOs) fórmico (70\%) e propiônico (30\%) na ração. O delineamento foi inteiramente ao acaso com cinco tratamentos e cinco repetições de 40 aves. As rações foram baseadas em milho, farelo de soja e óleo de soja e adequadas em todos os nutrientes. De um a 21 dias de idade foram afetados de forma quadrática o peso vivo, o ganho de peso e o consumo de ração. Com $2 \%$ de AOs na ração foram reduzidos o peso vivo e o ganho de peso dos frangos. O consumo de ração aumentou com 0,25 e $0,5 \%$ e foi reduzido com $2 \%$ dos AOs. De um a 42 dias de idade, apenas o consumo de ração foi afetado de forma quadrática, sendo aumentado nos níveis de 0,25 e $0,5 \%$ e reduzido com $2 \%$ de AOs. A mistura dos AOs em dosagens efetivas no controle de salmonelas não afetou o desempenho das aves, sendo que o nível de $1 \%$ de inclusão proporcionou desempenho similar ao das aves não tratadas.

Palavras-chave: Salmonella, frangos de corte, desempenho, segurança dos alimentos
\end{abstract}

\section{INTRODUCTION}

The growth in poultry production observed in recent decades resulted from contributions of some technologies and innovations in the fields of genetics, health, nutrition, management, environment, and others. Antimicrobial feed additives used as growth promoters were of great help to maintain high poultry productivity. The generalized use of antimicrobial feed additives has led to the development of resistant enterobacterial strains, includ- ing Escherichia coli and Salmonella sp., and enhanced the faecal excretion of Salmonella (Barrow, 1999).

The contamination of products of animal origin for human consumption inducing infections in consumers have been frequent in some countries and represent a great concern for governmental organisms, having resulted in voluminous medical expenses and productivity losses. Kuana (2001), mentioned that Salmonella is responsible for 1 to 4 million alimentary intoxication cases annually in the United States alone. 
Broiler chicken meat, being a major food source, is the most significant item in relation to human health because of the incidence of salmonella. When biosecurity actions are adopted in poultry production plants, care must be taken with regard to the possibility of salmonella reintroduction. Rations and animal raw materials are possibly the most important ways of contamination by this pathogen in poultry, as well as in other animals.

The incidence of salmonella in feed ingredients and rations in a feed meal plant was studied by Albuquerque et al. (1995), who verified the occurrence of Salmonella in $19.85 \%$ of the feed ingredient samples (136 samples). Among those samples, animal ingredients and vegetable products showed $50 \%$ and $12.5 \%$ contamination, respectively.

Among the alternatives to control the Salmonella dissemination in broiler chickens, stand the use of organic acids and the addition of probiotic or anaerobic cecal microbiota to poultry feeds. Andreatti Filho \& Sampaio (1999) demonstrated that the use of anaerobic cecal microbiota reduced the amount of $S$. enteritidis in poultry feces, without completely eliminating it. In another study, conducted by Oliveira (1996), various organic acid combinations were tested to prevent Salmonella contamination through the ration in day-old chicks, and it was observed that a mixture of formic (70\%) and propionic acid (30\%), at a $0.8 \%$ dose, was efficient to eliminate $S$. enteritidis and S. thyphimurium, both of great importance in human health.

The use of organic acids as feed additives in broiler chicken feeds has been questioned; several researchers (Patten \& Waldroup, 1988; Runho et al., 1997) observed an increase in performance; however, in other studies, Izat et al. (1990b), and Cave (1982) obtained poorer performances. The objective of this study was to evaluate the performance of male broiler chickens fed diets containing increasing levels of an organic acid mixture consisting of formic (70\%) and propionic acid (30\%).

\section{MATERIAL AND METHODS}

One thousand day-old male chicks from a commercial incubator were used. Chicks were maintained in an experimental concrete-floored chicken house with rice hulls bedding, distributed in 25 pens equipped with infrared light heaters and side curtains. Feed and water were supplied ad libitum.

The 42-day experimental period was divided into three stages: one to 21,22 to 35 , and 36 to 42 days of age. Rations were based on yellow corn, soybean meal, and soybean oil (Table 1), and were formulated to meet

Table 1 - Percentage composition and calculated nutritional levels for the basal diet.

\begin{tabular}{|c|c|c|c|}
\hline Ingredient & Starter & Grower & Finisher \\
\hline Yellow corn & 54.606 & 58.984 & 59.037 \\
\hline Soybean meal & 35.862 & 31.098 & 31.088 \\
\hline Soybean oil & 3.596 & 4.270 & 4.252 \\
\hline Limestone & 0.938 & 0.920 & 0.920 \\
\hline Dicalcium phosphate & 2.268 & 2.061 & 2.060 \\
\hline DL-methionine & 0.140 & 0.128 & 0.128 \\
\hline Salt & 0.300 & 0.300 & 0.300 \\
\hline Vitamin $\operatorname{mix}^{1}$ & 0.100 & 0.080 & 0.080 \\
\hline Trace mineral mix $^{2}$ & 0.050 & 0.050 & 0.050 \\
\hline Cl-choline $(60 \%)$ & 0.080 & 0.040 & 0.020 \\
\hline Avoparcin ${ }^{3}$ & 0.010 & 0.010 & 0.010 \\
\hline Anti-coccidial & $0.050^{4}$ & $0.060^{5}$ & - \\
\hline Starch $^{6}$ & 2.00 & 2.00 & 2.00 \\
\hline \multicolumn{4}{|c|}{ Calculated levels } \\
\hline \multicolumn{4}{|l|}{ Nutrient } \\
\hline $\operatorname{ME}\left(\mathrm{kcal} \mathrm{kg}^{-1}\right)$ & 3,000 & 3,100 & 3,100 \\
\hline $\mathrm{CP}(\%)$ & 21.00 & 19.20 & 19.20 \\
\hline Methionine (\%) & 0.464 & 0.429 & 0.429 \\
\hline Met.+cys. (\%) & 0.810 & 0.750 & 0.750 \\
\hline Lysine $(\%)$ & 1.154 & 1.028 & 1.028 \\
\hline Triptophan (\%) & 0.283 & 0.255 & 0.255 \\
\hline Threonine $(\%)$ & 0.824 & 0.754 & 0.754 \\
\hline Nonphytate Phosphorus (\%) & 0.50 & 0.46 & 0.46 \\
\hline Calcium $(\%)$ & 1.00 & 0.93 & 0.93 \\
\hline
\end{tabular}


nutritional requirements established by Rostagno et al. (1994). Treatments consisted of the inclusion of a mixture of organic acids (OAs), formic and propionic (at a ratio of $70 \%: 30 \%$, respectively), to replace starch at the levels of $0,0.25,0.5,1.0$, and $2 \%$ in the the ration.

The variables studied were live weight at 21 and 42 days of age, and weight gain, feed intake, feed-to-gain ratio and mortality from day one to 21 , and from day one to 42. Trial was set up in a completely randomized design, with five treatments and five replications of 40 birds. Analyses of variance were run according to the PROC GLM procedure, as well as regression analyses, with the OAs percentages of inclusion as explanatory variables, according to the PROC REG procedure of the SAS program.

\section{RESULTS AND DISCUSSION}

Performance of broiler chicken at 21 days of age was affected by the inclusion of OAs in the ration. Live weight, feed intake, and daily gain were affected ( $P \leq$ 0.01 ) by the treatments (Table 2 ), but feed-to-gain ratio and mortality $(P>0.05)$ were not.

Live weight on day 21 was affected $(P \leq 0.05$; Figure 1) by the inclusion of OAs in the diet. The $0.5 \%$ level showed a slight reduction in live weight while the $1 \%$ and $2 \%$ levels showed higher reductions, but the inclusion of $0.25 \%$ OAs did not affect live weight.

Feed intake was also affected in a quadratic form by the inclusion of OAs in the diet $(P \leq 0.10$; Figure 2$)$. The 0.25 and $0.5 \%$ OAs inclusion levels induced a slight increase in feed intake, but the $2 \%$ level induced a marked decrease $(12.5 \%)$, while the $1 \%$ level resulted in a feed intake value similar to the control without addition of OAs.

Weight gain from one to 21 days of age was affected in the same way as live weight at 21 days $(P \leq$

Table 2 - Performance of broiler chickens from one to 21 days of age receiving diets with increasing levels of OAs (formic 70\%: propionic 30\%).

\begin{tabular}{|c|c|c|c|c|c|}
\hline Treat. $^{1}$ & $\mathrm{LW}^{2}$ & $\mathrm{FI}^{2}$ & $\mathrm{WG}^{2}$ & $\mathrm{~F} / \mathrm{G}^{3}$ & $\mathrm{MR}^{3}$ \\
\hline & \multicolumn{4}{|c|}{ - - - } & $\%$ \\
\hline $\mathrm{BD}$ & 0.736 & 1.080 & 0.690 & 1.56 & 0.5 \\
\hline $\mathrm{BD}+0.25$ & 0.732 & 1.132 & 0.687 & 1.65 & 1.5 \\
\hline $\mathrm{BD}+0.5$ & 0.729 & 1.111 & 0.684 & 1.62 & 1.0 \\
\hline $\mathrm{BD}+1.0$ & 0.725 & 1.082 & 0.679 & 1.59 & 1.5 \\
\hline $\mathrm{BD}+2.0$ & 0.669 & 0.945 & 0.624 & 1.51 & 0.5 \\
\hline CV (\%) & 2.57 & 7.09 & 2.72 & 5.98 & 150 \\
\hline
\end{tabular}

${ }^{1}$ Treatments indicated by basal diet (BD) and its corresponding OAs percentage. ${ }^{2}$ Live weight (LW), feed intake (FI), and weight gain (WG) means from day one to day 21 differ by the F test $(P \leq 0.01)$. ${ }^{3}$ Feed-to-gain ratio (F/G) and mortality (MR) means did not differed by the $\mathrm{F}$ test $(P>0.05)$.
0.05; Figure 3), demonstrating a quadratic effect of organic acid addition on that variable. At the $0.5 \%$ level, weight gain was not affected; however, above $1 \%$ it had a marked effect compared with the treatment without addition of OAs. The $2 \%$ level decreased weight gain by approximately $60 \mathrm{~g}(9.5 \%)$ in relation to chickens that did not consume OAs with their diet.

With regard to usage levels, the formic and propionic organic acid mixture affected the performance of chickens at 21 days of age. When either formic acid (Izat et al., 1990b) or the formic and propionic acid mixture (85\%: 15\%) (Waldroup et al., 1995) was added at $1 \%$ to the broiler chicken ration in the initial period, weight gain was not affected. However, Cave (1982) reported that the weight gain of broiler chickens was reduced with a $3 \%$

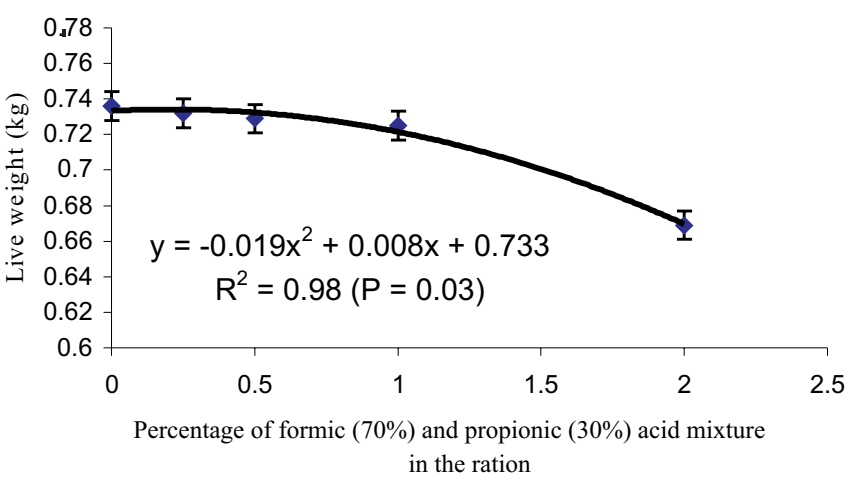

Figure 1 - Effect of organic acid mixture in the ration on live weight at 21 days of age (means \pm mean-square error).

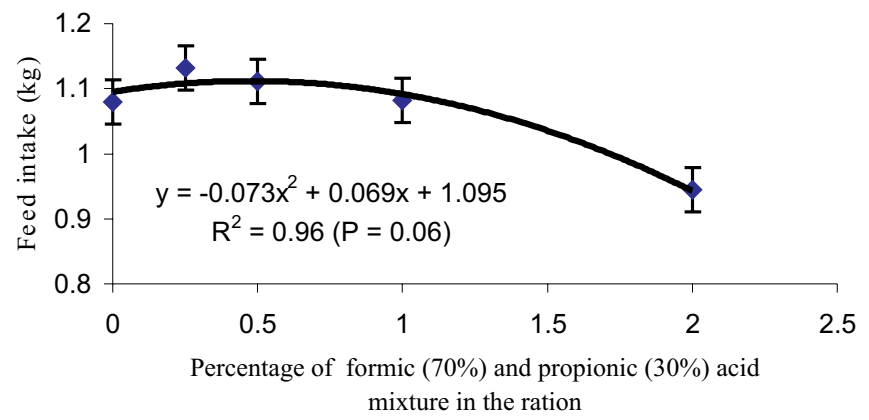

Figure 2 - Effect of organic acid mixture in the ration on feed intake at 21 days of age (means \pm mean-square error).

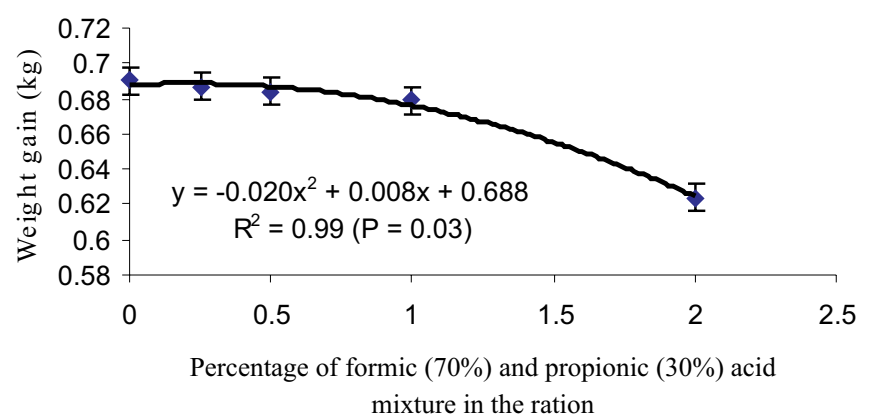

Figure 3 - Effect of organic acid mixture in the ration on weight gain at 21 days of age (means \pm mean-square error). 
dose of propionic acid in their diet. In this study, weight gain followed feed intake (Figures 2 and 3); Pinchasov \& Jensen (1989) studied several organic acids, including formic and propionic, and showed that only propionic acid had a significant action in reducing feed intake. As a matter fact, Cave (1978) had already indicated that propionic acid plays a role in the satiation regulatory system, since the intraperitoneal injection of this organic acid into broiler chickens suspended intake for 0.5 to 1.5 hours.

From one to 42 days of age, a difference ( $P \leq$ 0.05 ) was observed only regarding feed intake. Live weight and weight gain did not differ $(P>0.05)$ among treatments; however, the live weight and weight gain means at 42 days for the treatment involving the addition of $2 \%$ OAs mixture were lower, nearly $80 \mathrm{~g}$ (3.5\% of live weight and weight gain), than the means for nontreated chicken. In the same way, feed-to-gain ratio and mortality were not affected by the treatments $(P>0.05$, Table 3).

Similarly to this study, an $80 \%$ formic acid and $20 \%$ propionic acid mixture added at $1 \%$ to broiler chicken ration (Kaniawati et al., 1992), and 1\% formic acid or $1.45 \%$ calcium formate (Izat et al., 1990a) did not affect live weight and feed-to-ratio at 42 days. However, Patten \& Waldroup (1988) verified that the addition of $1.5 \%$ calcium formate to the ration reduced the weight of broiler chickens at 42 days.

Feed intake from one to 42 days of age was affected ( $\mathrm{P} \leq 0.10$; Figure 4$)$ by the inclusion of OAs in the diet. The 0.25 and $0.5 \%$ inclusion levels caused an increase in feed intake of about $117 \mathrm{~g}$ and $53 \mathrm{~g}$ per chicken, respectively, from one to 42 days of age, when compared with the treatment without addition of OAs. The $1 \%$ inclusion level of the OAs mixture resulted in a feed intake value similar to that observed for the zero level of addition; the $2 \%$ level of addition of the mixture decreased feed intake by nearly $240 \mathrm{~g}$ of ration in that pe-

Table 3 - Broiler chicken performance from one to 42 days of age receiving diets with increasing OAs levels (formic 70\%: propionic 30\%).

\begin{tabular}{|c|c|c|c|c|c|}
\hline Treat. $^{1}$ & $\mathrm{LW}^{2}$ & $\mathrm{FI}^{3}$ & $\mathrm{WG}^{2}$ & $\mathrm{~F} / \mathrm{G}^{2}$ & $\mathrm{MR}^{2}$ \\
\hline & \multicolumn{4}{|c|}{-.-. } & $\%$ \\
\hline $\mathrm{BD}$ & 2.380 & 4.372 & 2.334 & 1.87 & 2.0 \\
\hline $\mathrm{BD}+0.25$ & 2.360 & 4.489 & 2.316 & 1.94 & 10.0 \\
\hline $\mathrm{BD}+0.5$ & 2.344 & 4.425 & 2.298 & 1.92 & 7.5 \\
\hline $\mathrm{BD}+1.0$ & 2.381 & 4.388 & 2.336 & 1.87 & 5.0 \\
\hline $\mathrm{BD}+2 . \mathrm{O}$ & 2.301 & 4.128 & 2.255 & 1.83 & 4.0 \\
\hline CV (\%) & 2.47 & 3.53 & 2.52 & 3.31 & 75.96 \\
\hline
\end{tabular}

${ }^{1}$ Treatments indicated by basal diet (BD) and its corresponding OAs percentage. ${ }^{2}$ Live weight (LW), weight gain (WG), feed-gain ratio $(\mathrm{F} / \mathrm{G})$ and mortality (MR) means from day one to day 42 did not differ by the $\mathrm{F}$ test $(P>0.05) .{ }^{3}$ Cumulative feed intake (FI) from one to 42 days of age differed by $\mathrm{F}$ test $(P \leq 0.05)$.

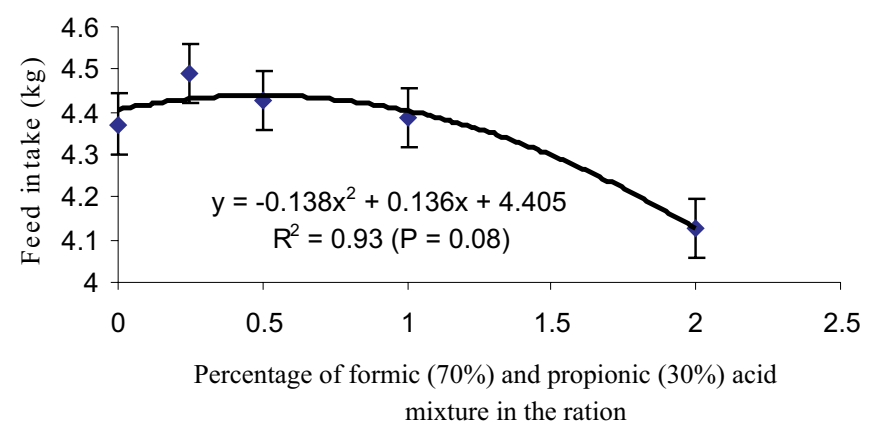

Figure 4 - Effect of organic acid mixture in the ration on feed intake at 42 days of age (means \pm mean-square error).

riod. This reduction in feed intake, as discussed below, is in agreement with results in the literature, but the feed intake increase herein observed with the $0.25 \%$ OAs level had not been reported yet. This increase was not followed by a corresponding increase in live weight, resulting in a quadratic effect $(P \leq 0.10)$ on feed-to-gain ratio, which was $3.7 \%$ worse in the treatment containing $0.25 \%$ OAs. In other papers dealing with OAs inclusion in the ration, an effect on feed-to-gain ratio was not ordinarily observed (Pinchasov \& Jensen, 1989; Kaniawati et al., 1992; Waldroup et al., 1995).

Chicken mortality was not affected by the treatments in the two periods $(P>0.05)$. Mortality was low in the starting period (Table 2); however, a great increase was observed for the entire period (Table 3); the mortality observed in the period from 22 to 42 days of age probably resulted from heat stress caused by a hot wave in the sixth week, and was not related to treatments.

Up to 21 days the difference in live weight between treatments with zero and $2 \%$ OAs was close to 60 g; for the entire period (42 days) it was 80 g. After 21 days of age, treatments had minor impact on chicken growth, and the main impact of the acids on growth resulted from nutrient restriction, promoted by a lower feed intake for chickens that fed on $2 \%$ of the OAs mixture, which occurred in the first 3 weeks of age. The $2 \%$ level of OAs promoted a decrease of about $9 \%$ in feed intake from one to 21 days, $3.3 \%$ from 22 to 42 days, and $5.5 \%$ from one to 42 days, in comparison to the basal diet. Deaton (1995) reported that feed-to-gain ratio improved and live weight was reduced in the total rearing period for broiler chickens under feed restriction between seven and 14 days of age when compared to chickens with no feed restriction. The early feed intake restriction by supplying 2\% OAs may have determined the reduction in weight gain observed by the end of the experimental period.

With regard to the use of these OAs, the economic factor may be determinative of the decision of using them. The levels established by Oliveira (1996) for control of salmonella in rations and the performance of 
broiler chicken fed diets containing these acids indicate that the $0.8 \%$ OAs level (which controls S. enteritidis) and the $0.4 \%$ level (which controls $S$. typhimurium and $S$. agona) could be added to broiler chicken diets, because they are efficient in controlling these bacteria and safe regarding the performance of chickens.

In short, the formic (70\%) and propionic acid (30\%) mixture may be used in broiler chicken rations at levels (up to 1\%) which do not affect broiler chicken performance and are effective in eliminating salmonella. Costs and operational care required in the use of organic acids by feed mills will constitute a restriction for the use of these products for broiler chickens, without limiting their usage under situations where they are justified.

\section{REFERENCES}

ALBUQUERQUE, R.; ITO, N.M.K.; MIYAJI, C.I. Ocorrência de salmonelas em ingredientes, rações e "swabs" de pó colhidos em fábricas industriais de rações. In: CONFERÊNCIA APINCO'95 DE CIÊNCIA E TECNOLOGIA AVÍCOLAS, Curitiba, 1995. Trabalhos de pesquisa. Campinas: FACTA, 1995. p.161-162.

ANDREATTI FILHO, R.L.; SAMPAIO, H.M. Probióticos e prebióticos. Revista de Educação Continuada do CRMV-SP, v.2, p.59-71, 1999.

BARROW, P.A. Salmonella em avicultura - problemas e novas idéias de possibilidades de controle. Revista Brasileira de Ciência Avícola, v.1, p.9-16, 1999.

CAVE, N.A.G. The influence of non-sterified fatty acids on feeding activity of chicks. Poultry Science, v.57, p.1124-1128, 1978.

CAVE, N.A.G. Effect of dietary short and medium-chain fatty acids on feed intake by chicks. Poultry Science, v.61, p.1147-1153, 1982.

DEATON, J.W. The effect of early feed restriction on broiler performance. Poultry Science, v.74, p.1280-1286, 1995.

IZAT, A.L.; ADAMS, M.H.; CABEL, M.C.; COLBERG, M.; REIBER, M.A.; SKINNER, J.T.; WALDROUP, P.W. Effects of formic acid or calcium formate in feed on performance and microbiological characteristics of broilers. Poultry Science, v.69, p.1876-1882, 1990a.
IZAT, A.L.; TIDWELL, N.M.; THOMAS, R.A.; REIBER, M.A.; ADAMS, M.H.; COLBERG, M.; WALDROUP, P.W. Effects of a buffered propionic acid in diets on the performance of broiler chickens and on microflora of intestine and carcass. Poultry Science, v.69, p.818-826, 1990b.

KANIAWATI, S.; SKINER, J.T.; WALDROUP, P.W.; IZAT, A.L.; COLBERG, M. Effects of feeding organic acids to broilers on performence and salmonellae colonization of the ceca and/or contamination of the carcass. Poultry Science, v.71, p.159, 1992. Supplement 1.

KUANA, S. Pontos críticos no controle de Salmonella em fábricas de rações. In: MATTOS, W.R.S. (Ed.) A produção animal na visão dos brasileiros. Piracicaba: FEALQ, 2001. p.134-140.

OLIVEIRA, E. O uso de ácidos graxos de cadeia curta no controle de Salmonella em rações de aves. Piracicaba: USP/ESALQ, 1996. 72p. (Dissertação - Mestrado).

PATTEN, J.D.; WALDROUP, P.W. Use of organic acids in broiler diets. Poultry Science, v.67, p.1178-1182, 1988.

PINCHASOV, Y.; JENSEN, L.S. Effect of short-chain fatty acids on voluntary feed of broiler chicks. Poultry Science, v.68, p.1612-1618, 1989.

ROSTAGNO, H.S.; SILVA, D.J.; COSTA, P.M.A.; FONSECA, J.B.; SOARES, P.R.; PEREIRA, J.A.A.; SILVA, M.A. Composição de alimentos e exigências nutricionais de aves e suínos (tabelas brasileiras). 6.ed. Viçosa: Imprensa Universitária, 1994. 57p.

RUNHO, R.C.; SAKOMURA, N.K.; KUANA, S.; BANZATTO, D.; JUNQUEIRA, O.M.; STRINGHINI, J.H. Uso do ácido orgânico (ácido fumárico) nas rações de frangos de corte. Revista Brasileira de Zootecnia, v.26, p.1183-1191, 1997.

WALDROUP, A.; KANIAWATI, S.; MAUROMOUSTAKOS, A. Performance characteristics and microbiological aspects of broilers fed diets suplemented with organic acids. Journal of Food Protection, v.58, p.482-489, 1995.

Received April 25, 2002

Accepted April 23, 2004 